\title{
Transcultural theory in nursing care of women with infections
}

\author{
Teoria transcultural na assistência de enfermagem às mulheres com infecções \\ Teoría transcultural en la asistencia de enfermería a las mujeres con infecciones
}

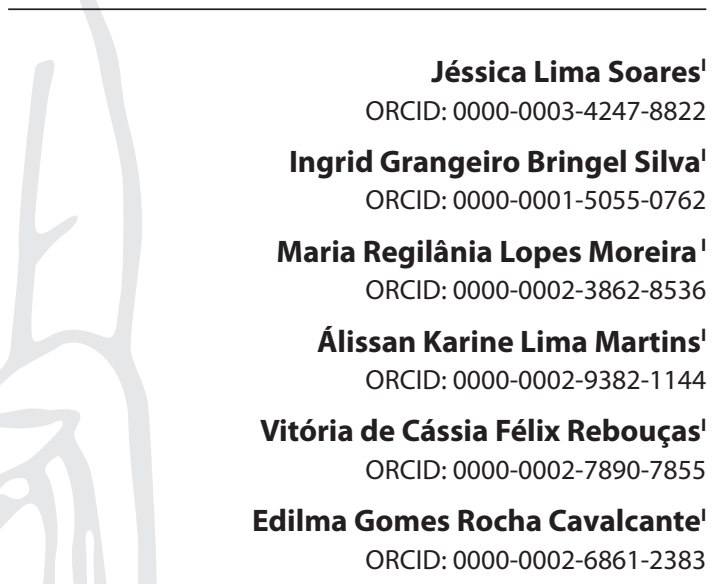

'Universidade Regional do Cariri. Crato, Ceará, Brazil.

How to cite this article: Soares JL, Silva IGB, Moreira MRL, Martins AKL, Rebouças VCF, Cavalcante EGR. Transcultural theory in nursing care of women with infections.

Rev Bras Enferm. 2020;73(Suppl 4):e20190586. doi: http://dx.doi.org/10.1590/0034-7167-2019-0586

Corresponding author:

Edilma Gomes Rocha Cavalcante

E-mail: edilma.rocha@yahoo.com.br

EDITOR IN CHIEF: Antonio José de Almeida Filho ASSOCIATE EDITOR: Maria Isabel Salamanca

Submission: $03-10-2019$

Approval: 04-30-2020

\begin{abstract}
Objective: To analyze how nurses consider, in their practice of healthcare, the sociocultural context of women with sexually transmitted infections. Method: Qualitative research, carried out in October 2017, with ten nurses working in teams of the Estratégia de Saúde da Família (Family Health Strategy). The data were collected through semi-structured interviews, subsequently transcribed, and submitted to the organization supported by the Discourse of the Collective Subject method and analyzed according to Madeleine Leininger's transcultural theory. Results: Nurses identified the sociocultural aspects of women with sexually transmitted infections and recognized the presence of influencing factors: technological, religious, economic, political, and legal, kinship and social, cultural values, and lifeways. Final Considerations: The study found that the provision of care by nurses in Primary Health Care is close to the sociocultural aspects of these women when considering the beliefs and values of each individual, especially regarding the life context and their care experiences.

Descriptors: Sexually Transmitted Diseases; Women; Nursing professionals; Nursing Theory; Transcultural Nursing.
\end{abstract}

\section{RESUMO}

Objetivo: Analisar como o enfermeiro considera, na sua assistência de saúde, o contexto sociocultural da mulher com infecção sexualmente transmissível. Método: Pesquisa qualitativa, realizada em outubro de 2017, com dez enfermeiros atuantes em equipes da Estratégia de Saúde da Família. A coleta ocorreu por meio de entrevistas semiestruturadas, posteriormente transcritas e submetidas à organização apoiada na técnica do Discurso do Sujeito Coletivo e analisadas segundo a teoria transcultural de Madeleine Leininger. Resultados: Os enfermeiros identificaram os aspectos socioculturais de mulheres com infecções sexualmente transmissíveis e reconheceram a presença de fatores influenciadores: tecnológicos, religiosos, econômicos, políticos e legais, de parentesco e sociais, valores culturais e modos de vida. Considerações finais: Verificou-se que a realização do cuidado pelos enfermeiros da Atenção Primária à Saúde se aproxima dos aspectos socioculturais dessas mulheres, quando consideram as crenças e os valores de cada indivíduo, sobretudo no contexto de vida e de suas experiências de cuidado.

Descritores: Doenças Sexualmente Transmissíveis; Mulheres; Profissionais de Enfermagem; Teoria de Enfermagem; Enfermagem Transcultural.

\section{RESUMEN}

Objetivo: Analizar como el enfermero considera, en su asistencia de salud, el contexto sociocultural de la mujer con infección sexualmente transmisible. Método: Investigación cualitativa, realizada en octubre de 2017, con diez enfermeros actuantes en equipes de la Estrategia de Salud de la Familia. La recogida ocurrió por medio de entrevistas semiestructuradas, posteriormente transcritas y sometidas a la organización apoyada en la técnica del Discurso del Sujeto Colectivo y analizadas segundo la teoría transcultural de Madeleine Leininger. Resultados: Los enfermeros identificaron los aspectos socioculturales de mujeres con infecciones sexualmente transmisibles y reconocieron la presencia de factores influyentes: tecnológicos, religiosos, económicos, políticos y legales, de parentesco y sociales, valores culturales y modos de vida. Consideraciones finales: Se ha verificado que la realización del cuidado por los enfermeros de la Atención Primaria a la Salud se acerca de los aspectos socioculturales de esas mujeres, cuando consideran las creencias y los valores de cada individuo, sobretodo en el contexto de vida y de sus experiencias de cuidado.

Descriptores: Enfermedades Sexualmente Transmisible; Mujeres; Profesionales de Enfermería; Teoría de Enfermería; Enfermería Transcultural. 


\section{INTRODUCTION}

Sexually transmitted infections (STIs) are among reproductive health problems, referring particularly to vertical transmission and fertility problems ${ }^{(1)}$. In Brazil, in 2016, 37,884 cases of HIV infection were reported in Sistema de Informação de Agravos de Notificação (SINAN - Brazilian Case Registry Database), from which 3,912 (10.3\%) cases were in the North region, 7,693 (20.3\%) cases in the Northeast region, 2,832 (7.5\%) in the Central-west region, $15,759(41.6 \%)$ in the Southeast and 7,688 (20.3\%) in the South $^{(2)}$. In the last five years, there has been a constant increase in the number of cases of acquired syphilis, congenital syphilis, and syphilis in pregnant women ${ }^{(3)}$.

A study carried out at the first health center in Latin America, in São Paulo, from 2013 to 2015, found that STIs predominated in males, young adults, of the white race, the ones who have a high level of education and, especially, among heterosexuals ${ }^{(4)}$, although some studies demonstrate a feminization process ${ }^{(5)}$. In health services, there is a greater increase in demand from women with STIs problems, presenting a higher prevalence in women in fertile age between 18 and 49 years, infected with HPV, trichomoniasis, syphilis, and genital herpes ${ }^{(6)}$.

Regarding risky sexual behavior, in the literature, there is a higher prevalence of STI in women partners of inmates due to the higher number of partners, sexual violence, sex for money, or under the influence of alcohol/drugs ${ }^{(7)}$. Black women also seem to be highly vulnerable to STIs, HIV/AIDS, and the explanatory hypotheses for this evidence are socioeconomic inequalities and institutional racism ${ }^{(8)}$. Vulnerability to STI transmission is also found especially in adolescents and is associated with social determinants, which involve the need for habits of talking about sexuality, integration between parents and health professionals, internet access, and considering alcohol consumption ${ }^{(9)}$.

Given the above, the vulnerabilities or factors that affect women with STIs should be considered in the context of the health team, in Primary Health Care, especially by nurses who provide care to STIs in different environments and have as their primary focus: screening, education, health counseling and the scope of nursing practice. Despite this consideration, when nursing does not work with the full scope for health care inherent to STIs, it may present a limitation of research related to the investigation of the practice's context and may not meet the needs of patients ${ }^{(10)}$.

The difficulties shown in nurses' approach to sexuality were identified in the scripts constructed during sexuality in childhood/adolescence, in the training process and the sexuality-care interface. These stereotypes and obstacles are interwoven with counseling when they are limited to guidelines on STI/HIV prevention practices, given the reduced number of access of these users to the health service ${ }^{(11-12)}$.

We highlight that sociocultural factors influence the acquisition of knowledge about STIs, having significant implications for prevention, treatment, and stigmatization of the disease, especially in older age groups ${ }^{(13)}$. Therefore, there is a need for considering cultural constructions in professional training ${ }^{(11)}$ and for these constructions implying quality in prioritizing the care of cases, depicting more significant preparation and security in communicating the exam results, confidentiality, and privacy ${ }^{(12)}$. Thus, it is essential to value the contexts of this assisted population, especially women with STIs who daily seek care in Primary Health Care.

From this perspective, aspects such as living ways, behaviors, and habits represent an integral part of each individual's culture. They influence health practices, including the area of knowledge and nursing practices that focus on Madeleine Leininger's theory of cultural care diversity and universality (TCCDU). The theory proposes care from a cross-cultural and holistic perspective, as each culture has its manner, patterns, expressions, and structures of knowing, explaining, and predicting well-being. It bases on three main aspects: 1) Cultural care preservation, 2) Cultural care accommodation, 3) Cultural care restructuring. In its application, the nurse considers individuals, families, or groups actively involved in the care process, thus avoiding culturally imposing health practices ${ }^{(14)}$.

Therefore, we observe a need for nurses to identify the sociocultural factors involved in the women' health-disease process concerning their contemporaneity, so that they develop care while identifying how it is received and accepted by the user. Thus, the following question arises: How do nurses consider sociocultural factors in their practice of healthcare of women with STIs?

\section{OBJECTIVE}

To analyze how nurses consider, in their practice of healthcare, the sociocultural context of women with STIs.

\section{METHODS}

\section{Ethical aspects}

The research followed the ethical precepts in force in Resolution 466/12 of the National Health Council, which is based on international guidelines on research involving human beings. The Research Ethics Committee approved the project of the Universidade Regional do Cariri. All participants signed two copies of the free and informed consent form. To guarantee anonymity, we coded the participants in pseudonyms formed by the letter "N" (nurse) followed by Arabic numerals from 1 to 10, according to the order of the interview (N1, N2 ... N10).

\section{Type of study}

This study is exploratory and descriptive research with a qualitative approach. It is an excerpt from the undergraduate thesis entitled "Empowerment and autonomy of women with STIs: perception and nursing care in the light of Madeleine Leininger's theory," for the Undergraduate Nursing course of the Universidade Regional do Cariri (URCA).

\section{Theoretical reference}

The theory of cultural care diversity and universality (TCCDU), proposed by Madeleine Leininger, was used as a reference. The following aspects of the theory were identified in the discourses: influencing factors (kinship and social factors, cultural values and lifeways), religious, economic, technological, political, and legal factors and educational factors ${ }^{(14)}$. They have repercussions on the construction of family care and health professionals. 


\section{Study setting}

The study was carried out in Unidades Básicas de Saúde (UBSPrimary Healthcare Unit) with Estratégia Saúde da Família (ESF) in a city from the south region of the state of the Ceará, Brazil. The city has a population of 268.248 inhabitants, 69 ESFs, being 63 urban and six rural. It is noteworthy that, during the study period, the ESF had $88.74 \%$ coverage of the population ${ }^{(15)}$.

\section{Collection and organization of data}

The data were collected in October 2017. The municipality had 67 ESF teams. We visited the 27 teams closest to the headquarters as they allowed larger access and lower risk for the researcher, given the collection period. After approaching ESF nurses, ten met the following inclusion criteria: being an ESF professional and having attended at least one woman with STIs in the UBS. Exclusion criteria were: being on vacation or leave from work during the data collection period (one), difficulty in scheduling the interview after three attempts (two), and not allowing recording the interviews (two).

The semi-structured interview was used, with questions about the socioeconomic and training profile of professionals, as well as the following guiding question: During assisting women with STIs, do you take into account the sociocultural context for the treatment? How do you perform it?

The interviews were conducted individually in a specific place in the UBS itself and had an average duration of 15 minutes. They were recorded on a smartphone device and transcribed in full. It is noteworthy that some redundancy or repetition was identified in the interviewees' statements. Therefore this condition leads to suspending the inclusion of new participants, according to the orientation set in the definition of theoretical saturation ${ }^{(16)}$.

\section{Data Analysis}

The interviews were fully transcribed and organized using the Discourse of the Collective Subject (DCS) method. It is a synthesis discourse, elaborated from fragments of similar discourses, organized through a data tabulation technique that groups statements without reducing them to quantity ${ }^{(17)}$. For this, the procedure was fully transcribing the content of the interviews, recognizing and clipping excerpts from the statements with higher semantic content, called Key-expressions (KE); identifying Central Ideas $(\mathrm{Cl})$; naming categories and categorizing Key-expressions according to the similarity of semantic content.

\section{RESULTS}

Ten nurses participated in the study, nine females and one male, being between 24 and 52 years old; the majority had a "married" marital status. Regarding color/race, six nurses declared themselves pardas (brown), three white and one black. Regarding the length of training, six had more than ten years; two nurses, between five and ten years; and two, less than five years. Eight completed a course with an approach to STIs or women's health after college. Nine had some specialization course, and one was doing the course.

The statements were organized through the DCS, which revealed seven Central Ideas $(\mathrm{Cl})$ presented in Chart 1. The analysis of the arising discourses considered the influencing factors pointed out in Leininger's theory.

Chart 1 - Discourse of the collective subject of nurses on the sociocultural context of women with sexually transmitted infection, Crato, Ceará, Brazil, 2017

\begin{tabular}{|c|c|c|}
\hline \multicolumn{3}{|c|}{ GUIDING QUESTION: DO YOU CONSIDER THE SOCIOCULTURAL CONTEXT FOR THE TREATMENT OF STIS? HOW DO YOU PERFORM IT? } \\
\hline Central Idea (Cl) & Discourse of the Collective Subject & $\begin{array}{l}\text { Influencing factors } \\
\text { according to } \\
\text { Leininger's theory }\end{array}$ \\
\hline $\begin{array}{l}\text { 1) Effective } \\
\text { Communication }\end{array}$ & $\begin{array}{l}\text { Yes, I have to speak in a way that she can understand, particularly because of her degree of } \\
\text { education. To speak her language, so they understand what the disease is, how it transmits. }\end{array}$ & Educational factors \\
\hline $\begin{array}{l}\text { 2) Social and } \\
\text { cultural interference } \\
\text { in diagnosis }\end{array}$ & $\begin{array}{l}\text { The social and cultural issue is complicated because they only seek the UBS when the disease } \\
\text { has already spread. They seek various forms; the mother teaches a way to treat. When They're } \\
\text { embarrassed to reach the mother, they look for a friend. Ultimately they seek the health unit. Usually, } \\
\text { they come full of doubts or with concepts already pre-established. }\end{array}$ & $\begin{array}{l}\text { Educational, kinship and } \\
\text { social factors, cultural } \\
\text { values and lifeways }\end{array}$ \\
\hline $\begin{array}{l}\text { 3) Linkages in } \\
\text { approaching the case }\end{array}$ & $\begin{array}{l}\text { I've been here for a long time, so I know pretty much what the profile is. You have to know how } \\
\text { to deal and know what to say so as not to create tension between them and among us. }\end{array}$ & $\begin{array}{l}\text { Cultural values and } \\
\text { lifeways }\end{array}$ \\
\hline $\begin{array}{l}\text { 4) Equity and } \\
\text { integrality in care }\end{array}$ & $\begin{array}{l}\text { I work in an equally way, but a patient who is in bad condition, we try to better provide care, continue } \\
\text { treatment, the integrality of care. If any patient needs to do a preventive examination or the unit is } \\
\text { not available at the moment, some women can seek other services. Patients who need to wait, I try to } \\
\text { refer to other points of assistance and facilitate access. Unfortunately, secondary care doesn't work the } \\
\text { way it should. When in the public network it is not available unfortunately she goes to the private. }\end{array}$ & $\begin{array}{l}\text { Technological, economic, } \\
\text { political and legal factors }\end{array}$ \\
\hline $\begin{array}{l}\text { 5) Identifying the } \\
\text { socioenvironmental } \\
\text { context }\end{array}$ & $\begin{array}{l}\text { You have to take into account everything, the area they live in; sometimes, it does not have } \\
\text { basic sanitation. Husbands who are drug users or drug dealers. You have to consider their entire } \\
\text { environmental context; otherwise, you can't give assistance to them. }\end{array}$ & $\begin{array}{l}\text { Kinship and social, } \\
\text { political and legal }\end{array}$ \\
\hline $\begin{array}{l}\text { 6) Preservation of } \\
\text { confidentiality }\end{array}$ & $\begin{array}{l}\text { In the case of teenagers, we always give her the option that the treatment is confidential. Not necessarily } \\
\text { the } 14 \text {-year-old girl needs to come with her mother because they get shy and don't tell them everything } \\
\text { that happened, the risks [to] they have been exposed. When they come alone, they open up a little } \\
\text { more; they are more sincere. It's a way that I thought I'd better get into this teenager's life. }\end{array}$ & Kinship and social factors \\
\hline $\begin{array}{l}\text { 7) Religiosity versus } \\
\text { treatment }\end{array}$ & $\begin{array}{l}\text { A woman with a more conservative, more religious culture is much harder to approach. Because } \\
\text { she already has prejudice about her own sexuality. They have resistance to treatment. They're } \\
\text { ashamed to get the ointment or the condom in the pharmacy. I keep the female and male } \\
\text { condom condoms here in my room, and I show you how it works. }\end{array}$ & $\begin{array}{l}\text { Cultural values and } \\
\text { lifeways and religious } \\
\text { individuals. }\end{array}$ \\
\hline
\end{tabular}


Transcultural theory in nursing care of women with infections Soares JL, Silva IGB, Moreira MRL, Martins AKL, Rebouças VCF, Cavalcante EGR.

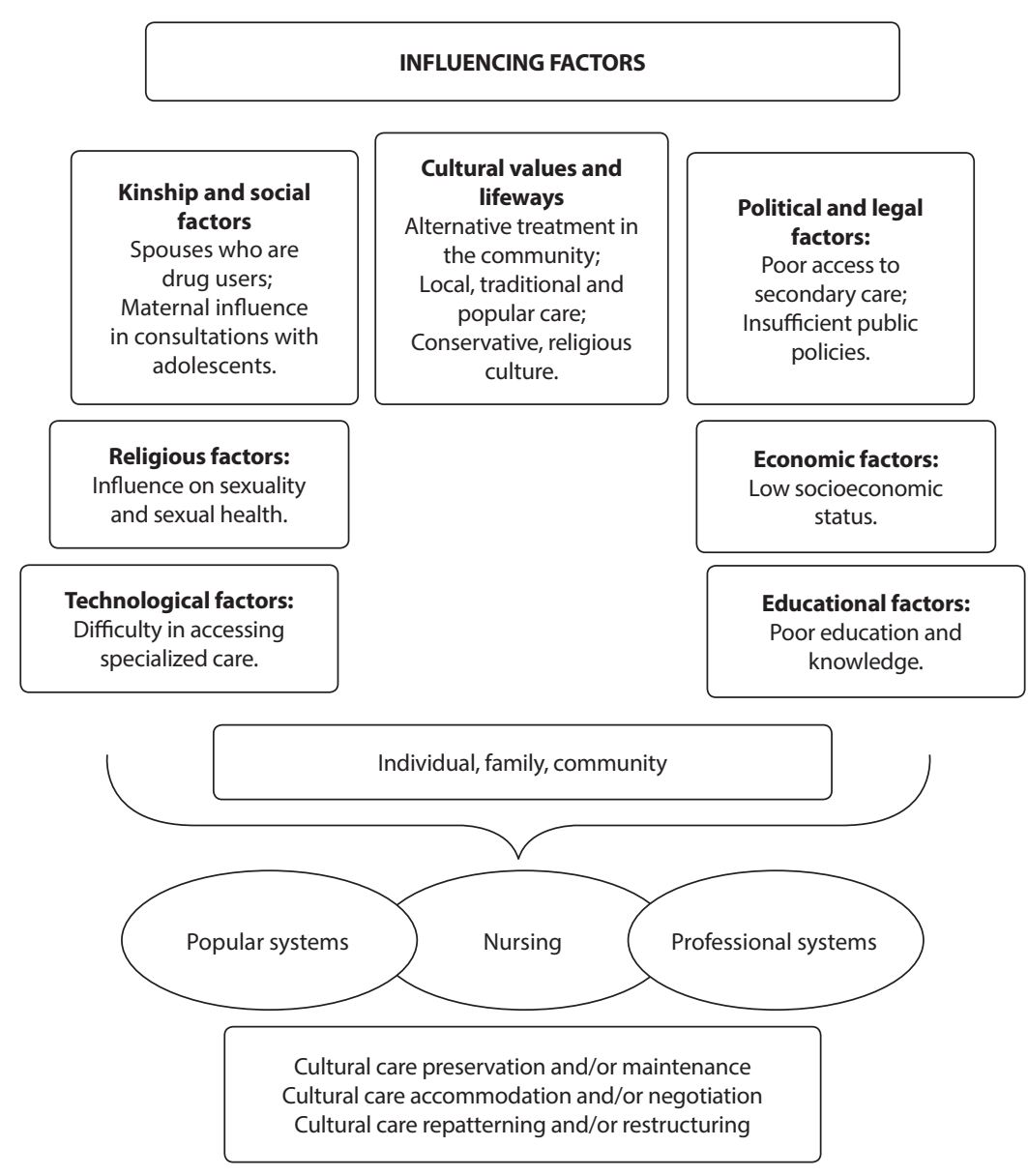

Source: Adapted from Madeleine Leininger

Figure 1 - Sunrise model - Identification of influencing factors of women with Sexually transmitted infections

Regarding the nurses' considerations, they recognize the social and cultural aspects of women with STIs attended in the ESF, as well as the adequate diagnosis, linkages, effective communication, and adherence to treatment. Also, the principles of equity and integrality are used to reduce the vulnerabilities of these women. Visualizing the influencing factors of Leininger's theory directly or indirectly interferes in nursing care for women with STIs, providing subsidies, and a starting point for elaborating a culturally congruent care (Figure 1).

\section{DISCUSSION}

In this study, the analysis of how nurses consider the sociocultural context of women with STIs in their practice health care pointed out the influencing factors, which should be perceived in planning cultural care and considered in the daily work process, evidencing the importance of addressing the TCCDU.

Effective communication was a concern of ESF nurses, recognized as an educational factor influencing the approach to women, due to the need to consider their level of education and understanding, to achieve effective communication and enable culturally congruent care. Effective communication is a useful tool to promote better adherence to treatment and optimize nursing care $^{(14)}$. In this sense, knowing the patient's level of education permeates more understandable orientations, positively impacting the health-disease process.

A study indicated that physicians' and nurses' practice of counseling on STIs was considered relevant, as it was included in family planning and school activities. However, unlike what this research reveals, it focused on biological parameters and was limited to specific disease orientation actions and prevention. The study identified little demand for service and fragility in communication, maintenance of confidentiality, and privacy of users ${ }^{(18)}$.

Social and cultural interferences in the diagnosis were presented as a result of the lack of access to accurate, valuable information, due to the search for care and health treatments in their social context. Kinship and social factors allow this to happen, as the possibility of alternative treatment in the community is granted, contributing to the mentioned doubts or pre-established concepts about the disease. A study conducted in Italy on the state of sexual health and reproductive needs of adolescents also identified this reality. The evidence showed that they had advanced signs and symptoms of STIs and were treated in the community. This condition is related to their unpreparedness in the context of sexual health education, which requires awareness of the subject at school age. It can have repercussions on the appropriate behavior, in the individual interest, and of the entire collectivity ${ }^{(19)}$.

Another international study, conducted among middle-aged adults in the United Kingdom, also pointed out the influence of social and cultural factors on knowledge about STIs throughout life, which reflect on the continuation of stigmatization, compromise the identification of symptoms, prevention and, consequently, early diagnosis and treatment ${ }^{(13)}$.

In the current study, the link established by the nurses with the population in their coverage area allowed, over time, more oriented care, as well as assistance to minimize the tensions between the couple/health professional, as it is an intimate problem which cultural issues permeate. Thus, the various factors and ways of communicating were considered to establish the case's best management. This interface and the contributions of cultural diversity in nursing valued care as they allow dialogue recognition, respect between civilizations and cultures to promote equity in health care ${ }^{(20)}$.

We understand that the knowledge of the cultural factors of women with STIs entails nurses' open dialogue and sensitive listening. A study conducted at a university in the United States reveals that health professionals - especially nurses - should address specific cultural attitudes and behaviors to the control of STIs, as they can influence exposure to them, especially HPV(21). In this sense, cultural aspects determine individuals' behaviors, and for contemplating cultural diversity, the ESF team's working actions should be the focus of care. 
In this study, in the $\mathrm{Cl}$ "equity and integrality" in care, we observed that nurses made references to technological (unavailable health technologies), economic, political and legal factors regarding the care of women with STIs and, in an attempt to ensure the integrality of care, they sought to refer them to the secondary care. However, faced with the difficulty of access, the women sought private service. The literature portrays the need to look at equity and integrality regarding the care of people with STIs in the follow-up of people with HIV/AIDS, at Primary and Secondary Care levels, to enable access and quality in care, which still presents moral, ethical, technical, organizational and political challenges ${ }^{(22)}$. It is still a challenge to maintain health services with quality and equity, the latter being necessary to ensure the flow of immediate care of women with STIs in secondary services.

The difficulty in ensuring the integration of health services in the context of STIs was identified in a systematic review study, which revealed models of integration of STIs services into the services of people living with the human immunodeficiency virus (HIV). It also addressed the need for an approach focused on people, gender equality and equity in health to improve accessibility and information, as well as a long-term treatment for improved service delivery in the context of STIs ${ }^{(23)}$.

In the $\mathrm{Cl}$ "Identifying the socioenvironmental context," nurses perceive that precarious housing conditions and relationships established with spouses who are drug users consist of factors that should be taken into account in care; and are identified in the risk behavior of STIs, as observed in the study with women users or former users of injection drugs, in the Metropolitan region of Santos ${ }^{(24)}$. These are cases of high complexity and vulnerability present in the practice of Primary Health Care, which require nurses' competencies in the approach, convocation, counseling, and treatment of spouses, from the perspective of increasing equity in access to the couple's reproductive health care.

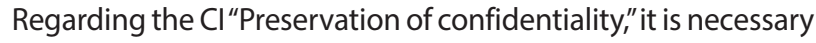
that nurses guarantee the confidentiality of the information given by the adolescents, collecting relevant information about sexual practices while building a relationship of trust between nurse and patient. Thus, it is possible to know the profile of adolescents' sexual behaviors, thus, elaborate educational interventions for this population, with a view to the deconstruction of prejudices and myths, the prevention of pregnancy and STIs, information about contraceptive methods, and, consequently, the promotion of adolescents' sexual health ${ }^{(25)}$.

In the current study, participants pointed out the maternal figure's presence during the nursing care of adolescents. Given this situation, individualized consultation was used as an alternative to favor trust and confidentiality. The nursing reception of adolescents in Primary Health Care plays an important role in the sexual education of adolescents, as parents still have difficulty talking about sexuality or do so superficially ${ }^{(26)}$.

Similarly, a study developed in the United States indicated the difficult communication between parents and adolescents regarding sexuality, due to the role of primary educators of the theme for their children. Among the factors that prevent the fulfillment of this educator role, there is a lack of knowledge, skills, or comfort. In this sense, parents can receive incentives from health professionals, educational and religious institutions, media, and professional educators, aiming at a greater understanding of the subject ${ }^{(27)}$.

This age group has a prevalence of STIs and requires screening and continued investment in education to prevent its late complications ${ }^{(28)}$. In this context, sexual health promotion actions can occur because when considering the participation of family, schools, and the medical community, we can know the reality of these young people, making it more feasible to share information ${ }^{(25)}$.

The Cl"Religiosity versus treatment" allowed identifying nurses' discourse based on the difficulty between the sexual approach and the resistance of performing the treatment of STIs in women who follow religious practices of a conservative nature. Nurses recognize that religion influences women's sexual health and sexuality; and that mandatory intervention should be avoided, requiring culturally congruent nursing care that reflects behavior change and adopting a healthier lifestyle.

Nurses need to develop strategies seeking respect for their faith and belief but combining them with the practice of health promotion and STIs prevention. A study with a group of young people of low socioeconomic status in Brazil found an association of religiosity with a decrease in the chances of starting sexual experiences $^{(29)}$. The role of family religiosity and students who practice it was also associated with a lower probability of engaging in any sexual activity and a higher probability of condom use. The study pointed out that religious influence positively interferes with university students' sexual behavior ${ }^{(30)}$.

Cultural factors related to care influence human expressions regarding health, disease, well-being, or coping with death and disabilities. The theory intends to provide harmonious care with individual or group cultural beliefs, practices, and values, consolidating the theoretical concept of "culturally congruent care." Thus, we envision the promotion of health, well-being, or assistance in coping with disabilities, diseases, or death in a culturally significant way ${ }^{(14)}$.

Therefore, there is a need for constructing this care based on the nurse-patient relationship, established aiming at creating a new lifestyle and care for health and well-being. This action requires the use of professionals' specific knowledge, as well as adjustments to nursing care based on recognized cultural factors. Thus, the competence of nurses in STIs care and in including sexuality in care practices points to the need for investment in professional education processes that break with learning by stereotype, incorporate a change in the health paradigm and consider, above all, the cultural constructions and vulnerabilities of users ${ }^{(11)}$.Training should also be based on effective communication and practices involving the different actors in the planning of actions, in the prevention of errors and damages; and from the perspective of the safe care practice ${ }^{(31)}$.

In the present study, we noted that the approach to cultural aspects is shown representatively by nurses working in the care of women with STIs. They recognize the interference of cultural factors in the care provided but feel unable to cope with macro-social issues.

\section{Study Limitations}

The study's main limitation is the impossibility of generalizing its findings, which is typical of the methodological design used and 
Transcultural theory in nursing care of women with infections Soares JL, Silva IGB, Moreira MRL, Martins AKL, Rebouças VCF, Cavalcante EGR.

the current theme as cultural factors are dependent on different contexts. Furthermore, we captured nurses' view of the care of women with STIs, and there is the possibility of expanding the research capturing the view of the women involved in this care.

It is noteworthy, however, that the data discussed here made it possible to understand important aspects to be introduced in nursing care planning in other contexts.

\section{Contributions to the nursing field}

Madeleine Leininger's TCCDU contributed as theoretical support to identify the factors that nursing, within Primary Health Care, should consider in the context and way of living of women with STIs. From the perspective of cultural care, primary health care nurses can identify the social, cultural, and environmental factors that involve these women and understand their care patterns. Given the above, it is interesting to nursing to know women with STIs to elaborate their culturally based work process and establish more effective care practices. As identified, we expect nurses to adopt more congruent actions that sustain the autonomy of women with STIs in the face of their vulnerabilities, including comprehensive care.

\section{FINAL CONSIDERATIONS}

The current study identified that nurses considered the influencing factors: technological, religious, economic, political and legal, kinship and social, cultural values and lifeways in the care of women with STIs. We understand that providing cultural nursing care requires knowing and considering each individual's beliefs and values, which requires knowledge beyond the signs and symptoms mentioned by the professionals.

It is noteworthy that nurses develop their care considering or not the influencing factors that will have a positive impact on care and also on their decision-making modes; and, once anchored in the model proposed by Leininger, it can value the diversity of cultural contexts in which women with STIs are placed.

\section{ACKNOWLEDGMENT}

Special thanks to Coordination for the Improvement of Higher Education Personnel, Capes, Brazil., For granting a scholarship for the Academic Master's Program in Nursing at the Regional University of Cariri (URCA).

\section{REFERENCES}

1. World Health Organization. Global health sector strategy on sexually transmitted infections 2016-2021 [Internet]. 2016[cited 2018 Jul 07]. Available from: http://www.who.int/reproductivehealth/publications/rtis/ghss-stis/en/

2. Ministério da Saúde (BR). Secretaria de Vigilância em Saúde; Departamento de Vigilância, Prevenção e Controle das Infecções Sexualmente Transmissíveis, do HIV/Aids e das Hepatites Virais. Boletim Epidemiológico HIV AIDS 2017 [Internet]. Editora do Ministério da Saúde. 2017. [cited 2018 Jul 07]. Available from: http://www.aids.gov.br/pt-br/pub/2017/boletim-epidemiologico-hivaids-2017

3. Ministério da Saúde (BR). Secretaria de Vigilância em Saúde - Departamento de Vigilância, Prevenção e Controle das ISTs, do HIV/Aids e das Hepatites Virais. Boletim Epidemiológico Sífilis 2017 [Internet]. Editora do Ministério da Saúde. 2017[cited 2018 Oct 04]. Available from: http://www.aids.gov.br/pt-br/pub/2017/boletim-epidemiologico-de-sifilis-2017

4. Marchezini RMR, Oliveira DAM, Fagundes LJ, Ciosak SI. Sexually transmitted infections in specialized service: who they are and who has them? Rev Enferm UFPE. 2018;12(1):137-49. doi: 10.5205/1981-8963-v12i01a25088p137-149-2018

5. Pinho AA, Cabral CS, Barbosa RM. Diferenças e similaridades entre mulheres que vivem e não vivem com HIV: aportes do estudo GENIH para a atenção à saúde sexual e reprodutiva. Cad Saúde Pública. 2017;33(12):e00057916. doi: 10.1590/0102-311x00057916

6. Farias IA, Silva DGKC. Estudo da prevalência de doenças sexualmente transmissíveis entre mulheres em idade fértil. Biota Amazônia. 2015;5(1):1.6. doi: 10.18561/2179-5746/biotaamazonia.v5n1p1-6

7. Martins DC, Pesce GB, Silva GM, Fernandes CAM. Sexual behavior and sexually transmitted diseases among the female partners of inmates. Rev Latino-Am Enfermagem. 2018;26:e3043. doi: 10.1590/1518-8345.2568.3043

8. Santo NJS. To be black and woman: dual vulnerability to STD/HIV/AIDS. Saúde Soc. 2016;25(3):602-618. doi: 10.1590/s0104-129020162627

9. Fontes MB, Cribelaro RC, Scartezini AM, Lima DD, Garcia AA, Fujioka RT. Determinant factors of knowledge, attitudes and practices regarding STD/AIDS and viral hepatitis among youths aged 18 to 29 years in Brazil. Ciênc Saúde Coletiva . 2017;22(4):1343-52. doi: 10.1590/1413-81232017224.12852015

10. Bungay V, Handlovsky I, Phillips JC, Prescott C. A scoping review of the literature on nursing practices with persons seeking care for sexually transmitted infections. J Clin Nurs. 2017;26(1-2):33-8. doi: 10.1111/jocn.13561

11. Santos SMP, Freitas JLS, Freitas MIF. Roteiros de sexualidade construídos por enfermeiros e a interface com a atenção em infecções sexualmente transmissíveis/HIV. Esc Anna Nery. 2019;23(4):e20190078. doi: 10.1590/2177-9465-ean-2019-0078p

12. Barbosa TLA, Gomes LMX, Holzmann APF, De Paula AMB, Haikal DSA. Aconselhamento em doenças sexualmente transmissíveis na atenção primária: percepção e prática profissional. 2015; 28(6):531-8. doi: doi:10.1590/1982-0194201500089

13. Dalrymple J, Booth J, Flowers P, Hinchliff S, Lorimere K. Socio-cultural influences upon knowledge of sexually transmitted infections: a qualitative study with heterosexual middle-aged adults in Scotland. Reprod Health Matt. 2016;(24):34-42. doi: 10.1016/j.rhm.2016.10.003

14. McFarrland MM, Wehbe-Alamah H. Leininger's Culture care diversity and university: a worldwide nursing theory. Canadá: Jones and Bartlett's Publishers Inc; 2005. 
Transcultural theory in nursing care of women with infections Soares JL, Silva IGB, Moreira MRL, Martins AKL, Rebouças VCF, Cavalcante EGR.

15. Ministério da Saúde (BR). Departamento de Atenção Básica. Cobertura da Atenção Básica [Internet]. 2018 [cited 2018 Mar 10]. Available from: https://egestorab.saude.gov.br/paginas/acessoPublico/relatorios/relHistoricoCoberturaAB.xhtml [ Links]

16. Rhiry-Cherques RH. Saturação em pesquisa qualitativa: estimativa empírica de dimensionamento. Af-Rev PMKT[Internet]. 2009[cited 2020 Mar 26];4(08):20-7. Available from: http://www.revistapmkt.com.br/Portals/9/Edicoes/Revista_PMKT_003_02.pdf

17. Lefevre F, Lefevre AMC. Discourse of the collective subject: social representations and communication interventions. Texto Contexto Enferm [Internet]. 2014 [cited 2018 Jun 20];23(2):502-7. Available from: http://www.scielo.br/pdf/tce/v23n2/0104-0707-tce-23-02-00502.pdf

18. Campos C. A comunicação terapêutica enquanto ferramenta profissional nos cuidados de enfermagem. Rev Serv Psiquiatr Hosp Prof Dr Fernando Fonseca, EPE. 2017;15(1):91-101. doi: 10.25752/psi.9725

19. Drago F, Ciccarese G, Zangrillo F, Gasparini G, Cogorno L, Riva S, et al. A survey of current knowledge on sexually transmitted diseases and sexual behaviour in Italian Adolescents. Int J Environ. Res Public Health. 2016;13(4):422. doi: 10.3390/ijerph13040422

20. Fontana R. A interculturalidade na formação dos profissionais de enfermagem. Rev Contexto Educ. 2019;34(109):36-51. doi: 10.21527/2179-1309.2019.109.36-51

21. Thomas TL, Yarandi HN, Dalmida SG, Frados A, Klienert K. Cross-Cultural Differences and Sexual Risk Behavior of Emerging Adults. J Transcult Nurs. 2015;26(1):64-72. doi: 10.1177/1043659614524791

22. Melo EA, Maksud I, Agostini R. Cuidado, HIV/Aids e atenção primária no Brasil: desafio para a atenção no Sistema Único de Saúde? Rev Panam Salud Publica. 2018;42:e151. doi: 10.26633/RPSP.2018.151

23. Kennedy CE, Haberlen SA, Narasimhan M. Integration of sexually transmitted infection (STI) services into HIV care and treatment services for women living with HIV: a systematic review. I. BMJ Open. 2017;21;7(6):e015310. doi: 10.1136/bmjopen-2016-015310

24. Haiek RC, Martin D, Rocha FCM, Ramiro FS, Silveira DX. Injection drug use among women in Metropolitan Region of Santos, São Paulo state, Brazil. Physis. 2016;26(3):917-937. doi: 10.1590/s0103-73312016000300011

25. Ferreira JPT, Miranda T, Baroni ALLR. Conhecimento sobre as DST entre adolescentes escolares em Vespasiano, Minas Gerais. Rev. Adolesc. Saúde [Internet]. 2016 [cited 2019 Oct 06];13(Supl. 2):51-59. Available from: http://www.adolescenciaesaude.com/detalhe_artigo. asp?id=584\#.

26. Nery IS, Feitosa JJM, Sousa AFL, Fernandes ACN. Approach to sexuality in the dialogue between parents and adolescents. Acta Paul Enferm. 2015;28(3):287-92. doi: 10.1590/1982-0194201500048

27. Breuner CC, Mattson G. AP Committee on adolescence, AAP Committee on psychosocial aspects of child and family health: sexuality education for children and adolescents. Pediatr. 2016;138(2):e20161348. doi: 10.1542/peds.2016-1348

28. Sá MI, Silva MT, Almeida D, Vieira B, Lima T, Conde C, et al. Infeções sexualmente transmissíveis e factores de risco nas adolescentes e jovens: dados de um Centro de Atendimento a Jovens. Nascer Crescer [Internet]. 2015 [cited 2019 Oct 09]; 24(2):64-9. Available from: http://www. scielo.mec.pt/pdf/nas/v24n2/v24n2a03.pdf

29. Elder CS, Koller S. Sexual risk-taking behavior: the role of religiosity among poor brazilian youth. Universitas Psychol. 2016;15(4):1-9. doi: 10.11144/Javeriana.upsy15-4.srbr

30. Quinn DA, Lewin A. Family religiosity, parental monitoring, and emerging adults' sexual behavior. Religions. 2019;10(2):114. doi: 10.3390/ rel10020114

31. Campelo CL, Sousa SMAS, Silvia LDC, Dias RS, Azevedo PR, Nunes FD, et al. Patient safety culture and the cultural nursing care. Rev Enferm UFPE. 2018;12(9):2500-6. doi: 10.5205/1981-8963-v12i9a235048p2500-2506-2018 